\title{
Movement of wild European lobsters Homarus gammarus in natural habitat
}

\author{
I. P. Smith*, A. C. Jensen, K. J. Collins, E. L. Mattey \\ School of Ocean and Earth Science, University of Southampton, Southampton Oceanography Centre, European Way, \\ Southampton SO14 3ZH, United Kingdom
}

\begin{abstract}
Most previous mark-recapture studies of the movement of European lobsters have used externally attached tags which were lost at ecdysis, restricting the range of possible recapture intervals. Published studies of this species with tags designed to be retained through ecdysis have focussed on artificially reared lobsters, or wild lobsters released in artificial habitat. Here, we report a mark-recapture study of the mobility of wild European lobsters conducted in 3 areas on the south coast of England, using persistent tags. Tagged lobsters were smaller than the fishery minimum landing size ( 50 to $84 \mathrm{~mm}$ carapace length) and were therefore likely to be predominantly sexually immature. The majority of these lobsters do not appear to undertake extensive alongshore or on-/offshore migrations. Recapture distances ranged from 0 to $45 \mathrm{~km}$, but $95 \%$ of recaptured lobsters moved $<3.8 \mathrm{~km}$ from their original release positions over periods of up to $862 \mathrm{~d}$. Distance moved did not differ between males and females, but there was a weak positive relationship between recapture distance and body size. The directional distribution of movements $>0.5 \mathrm{~km}$ differed between the 3 study areas and appeared to be related to the spatial configuration of local lobster habitat, but with a marked tendency for offshore movement in 2 of the areas. Movements $>5 \mathrm{~km}$ from all 3 release areas, which comprised $5 \%$ of recaptures after $>6$ mo, were generally undertaken by larger lobsters and were almost exclusively to the west or southwest, against the general direction of tide- and wind-generated residual water movement in the English Channel.
\end{abstract}

KEY WORDS: Lobster $\cdot$ Mark-recapture $\cdot$ Movements $\cdot$ Migrations $\cdot$ Tagging Resale or republication not permitted without written consent of the publisher

\section{INTRODUCTION}

In mobile species, locomotor movement is an important link between the behaviour of individuals and ecological processes. Density-dependent mechanisms underlying the structure and dynamics of populations and communities are often sensitive to short-term changes in the spatial distribution of individuals due to movement (Milinski \& Parker 1991). Such effects are likely to be interactive, since movement patterns may themselves depend on the density of competitors, predators and prey (Sutherland 1996). Decapod crustaceans exhibit various forms of habitat use, both within and among populations, such as territoriality,

*E-mail: philip.smith@soc.soton.ac.uk central place foraging, nomadism and migration, which are reflected in the movements of individuals and which have implications for survival, growth and reproduction (Herrnkind 1983, Spanier et al. 1988, Lawton \& Lavalli 1995, Vannini \& Cannicci 1995). Furthermore, several species of decapod appear to have important effects on benthic community structure through predation and disturbance (e.g. Ebling et al. 1964, Barkai \& Branch 1988, Robles \& Robb 1993, Lipcius \& Cobb 1994, Yamada \& Boulding 1996), and the range, timing and spatial distribution of foraging by decapod predators are potentially important determinants of their ecological consequences (Andrew \& MacDiarmid 1991, Scheibling 1996).

In commercially fished species, movement patterns impact on current methods of assessing and managing 'unit stocks' (Bannister 1986, Fogarty 1995, Lawton \& 
Lavalli 1995, Addison \& Bannister 1998). Information about movements is also needed to evaluate the feasibility of more recent concepts for sustainable resource use, such as stock enhancement (Bannister et al. 1994, Bannister \& Addison 1998), marine reserves (Perry et al. 1999) and 'ranching' techniques (Jensen et al. 2000).

The European lobster Homarus gammarus (L.) is a large, mobile decapod that preys on a wide range of benthic invertebrates (Hallbäck \& Warén 1972) and which supports valuable fisheries (Bannister 1986). Despite this, there is a lack of published information on demographic and temporal patterns in movement. This contrasts with the large number of studies on the American lobster $H$. americanus Milne Edwards (reviewed by Lawton \& Lavalli 1995; see also Estrella \& Morrissey 1997, Watson et al. 1999). Early mark-recapture studies of $H$. gammarus were designed primarily to estimate fishing mortality or growth rates, but they also provided limited information on movement. Most recaptures were made within $3 \mathrm{~km}$ of release sites over periods of around $6 \mathrm{mo}$, with a small proportion of recaptures indicating residual movements of up to 15 km (Thomas 1955, Simpson 1961, Gibson 1967). Movements appeared to be undirected, resulting in a gradual dispersion of tagged lobsters, subject to the constraints of available habitat and the spatial distribution of fishing effort (Simpson 1961, Hepper 1978). Hepper (1978) noted exchange of lobsters between nearshore and offshore fishing areas 10 to $15 \mathrm{~km}$ apart, but given the type of tag used and the study design, it was not possible to tell if there was a regular return migration.

These early tagging studies were limited by the use of externally attached tags on lobsters that were likely to moult, and thus shed the tag, within $1 \mathrm{yr}$ of release. This constrained the maximum recapture interval, so it

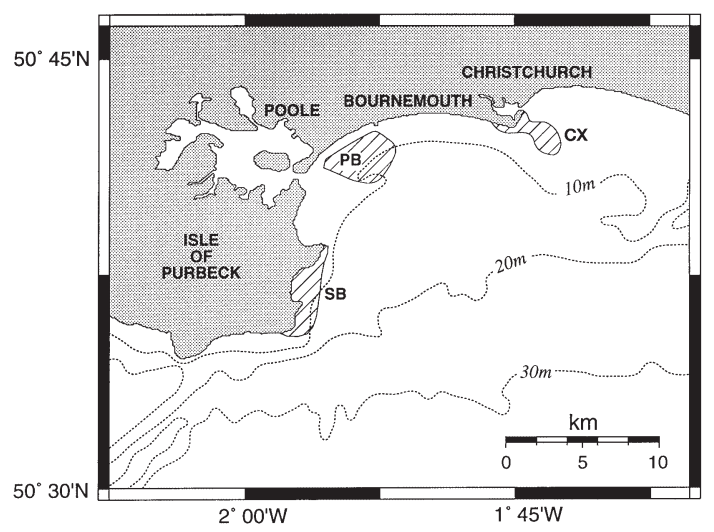

Fig. 1. Areas in which lobsters were captured, tagged and released. $\mathrm{PB}=$ Poole Bay, $\mathrm{CX}=$ Christchurch Ledge, $\mathrm{SB}=$ Swanage Bay was not possible to be certain that movements over greater distances did not occur over longer periods. In addition, non-moult tag loss rates were not known and some tag designs or handling procedures may have caused considerable initial tagging mortality (Gibson 1967). Lobsters were often landed before tagging and were therefore displaced from their initial capture location by an unknown (Thomas 1955, Simpson 1961, Hepper 1978) or considerable (Thomas 1955) margin before release, which may have affected their subsequent movement. More recently, ultrasonic tracking and electromagnetic telemetry have been used to study small-scale movement and activity of Homarus gammarus (Arnold et al. 1990, Collins \& Jensen 1992, van der Meeren 1997, I.P. Smith et al. 1998a,b, 1999), but these techniques are not well suited to monitoring many individuals over a large area (G.W. Smith et al. 1998, Smith et al. 2000) and they rely on externally attached transmitters which are shed at ecdysis.

The development of conventional tags that can be retained through ecdysis (so-called 'persistent' tags; Gundersen 1962, Jefferts et al. 1963, Scarratt \& Elson 1965, Ennis 1972, Chittleborough 1974, Bennett \& Lovewell 1983) allows recaptured lobsters to be identified after several years at liberty. However, the studies of Homarus gammarus movement using persistent tags published to date have been of hatchery reared lobsters released in natural habitat (Bannister et al. 1994, Latrouite 1998), or of wild lobsters in artificial habitat (Jensen et al. 1994), and they did not analyse movements in detail. Here, we describe a mark-recapture study using persistent tags to examine movements of wild $H$. gammarus in natural habitat over greater distances and longer time scales than are practicable with telemetry. We test the hypotheses suggested by earlier studies of this species that most lobsters do not undertake extensive movements (e.g. $>5 \mathrm{~km}$ ) and that there is no directional pattern to movements.

\section{MATERIALS AND METHODS}

Lobster tagging. On selected days during the period July 1990 to September 1993, lobsters Homarus gammarus less than the minimum legal landing size of $85 \mathrm{~mm}$ carapace length (CL), down to $50 \mathrm{~mm} \mathrm{CL}$, were caught, tagged and released in 3 areas on the south coast of England: Poole Bay ( $\mathrm{n}=1954)$, Christchurch Ledge $(n=999)$ and Swanage Bay $(n=272)$. These areas were chosen because they are neighbouring fishing grounds separated by at least $5 \mathrm{~km}$ (Fig. 1). Lobsters were sampled with the same types of trap as used in the local fishery: 'parlour' and 'inkwell' pots (entrances 18 and $25 \mathrm{~cm}$ diameter, respectively, mesh size 4 to $5 \mathrm{~cm}$, no other escape gaps incorporated) 
baited with mackerel and deployed on rocky seabed at depths of 3 to $15 \mathrm{~m}$. Most lobsters were tagged and released in summer (95\% during the months of June to September, the remainder in March to May).

Carapace length was measured from the rear of the eye socket to the posterior margin of the carapace to the nearest millimetre with vernier callipers and sex was determined by examination of the first pair of pleopods. A T-bar internal anchor tag (TBA1, yellow, $30 \times 2 \mathrm{~mm}$, Hallprint Pty. Ltd, Holden Hill, South Australia) bearing a unique number was inserted in the dorsal musculature between the cephalothorax and the first abdominal segment, to one side of the mid-line (to avoid the dorsal abdominal artery and gut), using a standard tag applicator (tagging gun 3030, Monarch Marking Systems, Miamisburg, Ohio). A polyethylene 'streamer' tag (yellow, $92 \times 3.5 \mathrm{~mm}$ with $40 \times 2 \mathrm{~mm}$ central cutaway, Hallprint) bearing the same number was inserted using the attached needle (subsequently discarded) horizontally into the dorsal musculature to a depth of no greater than $5 \mathrm{~mm}$ from the dorsal surface (to avoid the dorsal abdominal artery) and drawn through so that the end marker sections protruded from either side of the mid-line. Tag positioning was as illustrated by Jensen et al. (1994). Both types of tag can be retained through ecdysis (Jensen et al. 1994). After tagging, lobsters were released by hand from the surface near their capture location and the position indicated by a Decca navigator was noted.

Mean CL ( \pm SE) of tagged lobsters was $75.3 \pm$ $0.13 \mathrm{~mm}$ in Poole Bay, $75.5 \pm 0.18 \mathrm{~mm}$ at Christchurch Ledge and $76.0 \pm 0.35 \mathrm{~mm}$ in Swanage Bay (Table 1). Sex ratios in these areas were 52, 51 and $53 \%$ females, respectively. Only 10 ovigerous females were tagged, of which 4 were recaptured. The size at which lobsters from the study areas become sexually mature has not been studied in detail. At Selsey, $67 \mathrm{~km}$ east of Christchurch, the estimated CL at which $50 \%$ of females were mature was $83 \mathrm{~mm}$ (Free et al. 1992). On this basis, the majority of tagged lobsters would have been immature, but a proportion of the larger individuals may have been mature, or undergoing maturation.

Average annual minimum and maximum surface water temperatures at Bournemouth Pier (Fig. 1) during release and recapture periods were 6 and $19^{\circ} \mathrm{C}$, respectively. Mixing by wind and tide is normally sufficient to prevent marked stratification in the study area, thus these annual extremes correspond well with seabed measurements made at $12 \mathrm{~m}$ depth in Poole Bay from 1996 to 1997 (Smith et al. 1999).

Recaptures. Tagged lobsters recaptured during tagging sessions were measured, re-released and their capture location was recorded. In addition, a reward was offered to fishermen for recapture information,
Table 1. Size and sex distribution of tagged lobsters (\%). CL: carapace length; F: females; M: males

\begin{tabular}{|c|c|c|c|c|c|c|}
\hline \multirow[t]{2}{*}{$\begin{array}{l}\text { CL } \\
(\mathrm{mm})\end{array}$} & \multicolumn{2}{|c|}{$\begin{array}{l}\text { Poole Bay } \\
(\mathrm{n}=1954)\end{array}$} & \multicolumn{2}{|c|}{$\begin{array}{l}\text { Christchurch } \\
\text { Ledge } \\
(\mathrm{n}=999)\end{array}$} & \multicolumn{2}{|c|}{$\begin{array}{c}\text { Swanage } \\
\text { Bay } \\
(\mathrm{n}=272)\end{array}$} \\
\hline & $\mathrm{F}$ & $\mathrm{M}$ & $\mathrm{F}$ & $\mathrm{M}$ & $\mathrm{F}$ & M \\
\hline $50-54$ & 0.1 & 0.0 & 0.0 & 0.0 & 0.0 & 0.0 \\
\hline $55-59$ & 0.4 & 0.3 & 0.0 & 0.0 & 0.7 & 0.0 \\
\hline $60-64$ & 1.9 & 2.0 & 1.2 & 0.2 & 0.7 & 1.1 \\
\hline $65-69$ & 6.7 & 6.7 & 5.9 & 3.6 & 6.3 & 7.0 \\
\hline $70-74$ & 11.4 & 11.0 & 10.2 & 11.5 & 10.7 & 8.5 \\
\hline $75-79$ & 15.2 & 14.3 & 17.3 & 16.4 & 13.2 & 15.8 \\
\hline $80-85$ & 15.8 & 14.3 & 16.3 & 17.5 & 20.6 & 15.1 \\
\hline
\end{tabular}

including date and location of recapture and whether the lobster was landed or released (still undersized). Tags bore marks indicating that recaptures should be reported to the Ministry of Agriculture Fisheries and Food (MAFF), a procedure familiar to fishermen and the local fishery officers along the south coast of England from previous MAFF tagging studies of other species, as well as from material and activities to publicise the present study. This paper presents results based on recaptures reported up until December 2000 (>5 yr since the last reported recapture).

In this type of study, the spatial distribution of recaptures and the directions of movement indicated can be affected by spatial heterogeneity in the probabilities of recapture and reporting. One of the main determinants of probability of recapture is fishing effort. Quantitative information about the spatial distribution of lobster fishing effort data is not available, since effort is not regulated or recorded and the fleet comprises full- and part-time vessels which may also engage in fishing for other species. Nevertheless, intense lobster fishing is known to take place on suitable ground along the coast to the east and west of the study area, extending beyond the furthest reported recapture locations (see Gray (1995) for locations of fishing ports and approximate numbers of vessels operating from them). Of particular relevance to the possibility of detecting longdistance alongshore movements are the considerable number of lobster fishing vessels operating in the vicinity of Weymouth (36 km west of Swanage) and around the Isle of Wight (12 to $37 \mathrm{~km}$ to the east of Christchurch). Trawling for demersal finfish and trap fishing for brown crabs Cancer pagurus L., both of which may catch lobsters (Lovewell 1991), take place further offshore. Lobster fishing is carried on throughout the year, but fishing effort, catchability and hence catches are higher in summer (Edwards 1973, Hepper 1978).

Various determinants of lobster catchability in traps, such as the abundance of other lobsters and brown 
crabs (Addison \& Bannister 1998), could exhibit systematic spatial variation, which would tend to bias the pattern of movement estimated from tag recaptures. However, the spatial distribution of any such factors within the study area is not known. Several individual characteristics affect lobster catchability (Miller 1990) and therefore potentially influence the probability of recapture and average time at liberty for different categories of tagged lobster. Heterogeneity in catchability would affect the sample size of recorded movements by different categories of lobster, but could also bias estimates of their range of movement, if recapture intervals were not taken into account.

Statistical analysis. Movements of individual lobsters have been represented by the shortest distance between the original release location and the last recapture location. Where land was present between release and recapture positions ( $2 \%$ of recaptures), the shortest distance has been calculated via interjacent headlands. The incidence of movements in different directions (calculated from release to recapture positions) has been assessed from recaptures made more than $0.5 \mathrm{~km}$ from the release location, to reduce the effects of errors in position fixing. Frequency distributions of direction moved were bi- or multi-modal and were therefore not amenable to standard circular statistical analyses (Fisher 1993). Directions were therefore grouped into $30^{\circ}$ categories for analysis. In addition, special consideration has been given to the direction of movements greater than $5 \mathrm{~km}$, since these usually involved recapture in a different fishing area (in terms of the home port of the majority of the vessels fishing there) from that of first release.

Multi-factor analysis of frequencies has been carried out by log-linear analysis, with $G$-tests for change in goodness of fit (Sokal \& Rohlf 1995). Distance between

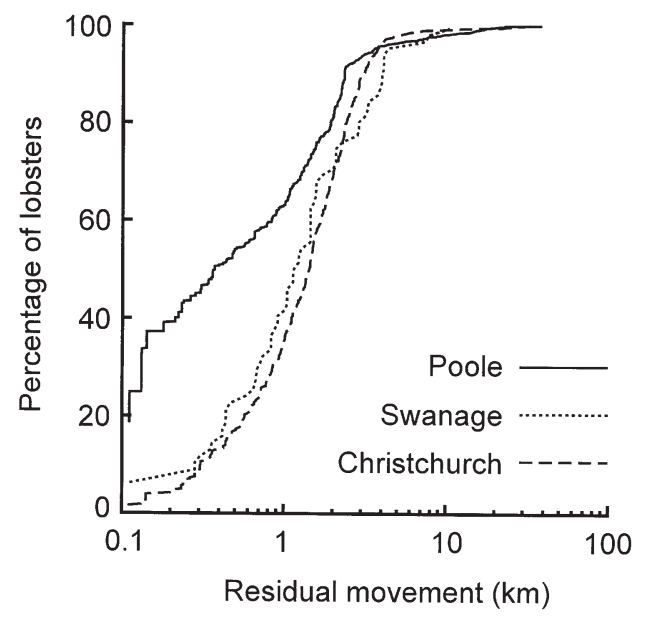

Fig. 2. Cumulative frequency distribution of distance between release and final recapture of tagged lobsters release and recapture has been analysed in relation to area of release, sex, CL, time at liberty and direction moved by general linear models (Neter et al. 1996). Recapture distance and time at liberty were normalised by log-transformation. Statistical analyses were performed with the computer program Systat for Windows, version 5 (Wilkinson et al. 1992), with a significance level of $5 \%$. The rate of tag loss prior to recapture was estimated over the interquartile range of recapture intervals from first recoveries of lobsters bearing both streamer and T-bar tags, or only one of either type by:

$$
P_{\mathrm{ST}}=\frac{N_{\mathrm{S}} N_{\mathrm{T}}}{\left(N_{\mathrm{ST}}+N_{\mathrm{S}}\right)\left(N_{\mathrm{ST}}+N_{\mathrm{T}}\right)}
$$

where $P_{\mathrm{ST}}=$ the estimated proportion of lobsters that had lost both types of tag, $N_{\mathrm{S}}=$ the number of recaptured individuals bearing only a streamer tag, $N_{\mathrm{T}}=$ the number of recaptured individuals bearing only a T-bar tag and $N_{\mathrm{ST}}=$ the number of recaptured individuals bearing both types of tag (Seber 1982). The standard error of this estimate was obtained from a bootstrap analysis of 1000 pseudoreplicate samples (Efron \& Tibshirani 1998).

\section{RESULTS}

Ultimate recapture rates of lobsters tagged in Poole Bay, at Christchurch Ledge and in Swanage Bay were $52.1,53.7$ and $27.9 \%$, respectively. Intervals between release and last recapture ranged from 1 to $862 \mathrm{~d}$, with a median of $87 \mathrm{~d}$. Most final recaptures occurred within 1 yr of release: 94.8, 97.0 and 93.4\% for Poole Bay, Christchurch Ledge and Swanage Bay, respectively. Of the lobsters which retained 1 or more tags at final recapture, at least $26 \%$ had moulted since initial release, indicated by a size increase of $>2 \%$ (to exclude measurement error; most moult increments were near $10 \%$ ). On this criterion, it was not possible to know whether lobsters greater than $84 \mathrm{~mm}$ CL at tagging and reported only as 'sizeable' ( $\geq 85 \mathrm{~mm} \mathrm{CL}$ ) by fishermen had moulted. Estimated loss of both tags $( \pm \mathrm{SE})$ averaged over the interquartile range of recapture intervals (39 to $213 \mathrm{~d}$ ) was $6 \pm 4.2 \%$.

Distances between release and recapture locations ranged from 0 to $45.1 \mathrm{~km}$, but $95 \%$ of recaptured lobsters moved less than $3.8 \mathrm{~km}$ from their original release sites (Fig. 2). Poole Bay lobsters were recaptured nearer to their release sites on average (mean $0.8 \mathrm{~km}, 95 \%$ confidence limit 0.69 to $0.83 \mathrm{~km}$ calculated from logtransformed data) than lobsters from the other 2 areas (Christchurch $1.4 \mathrm{~km}, 1.31$ to $1.51 \mathrm{~km}$, Swanage $1.4 \mathrm{~km}$, 1.12 to $\left.1.76 \mathrm{~km}, F_{2,1523}=56.6, \mathrm{p} \ll 0.001\right)$, despite the fact that mean recapture intervals did not differ significantly among the areas $\left(F_{2,1513}=2.30, \mathrm{p}=0.10\right)$. 

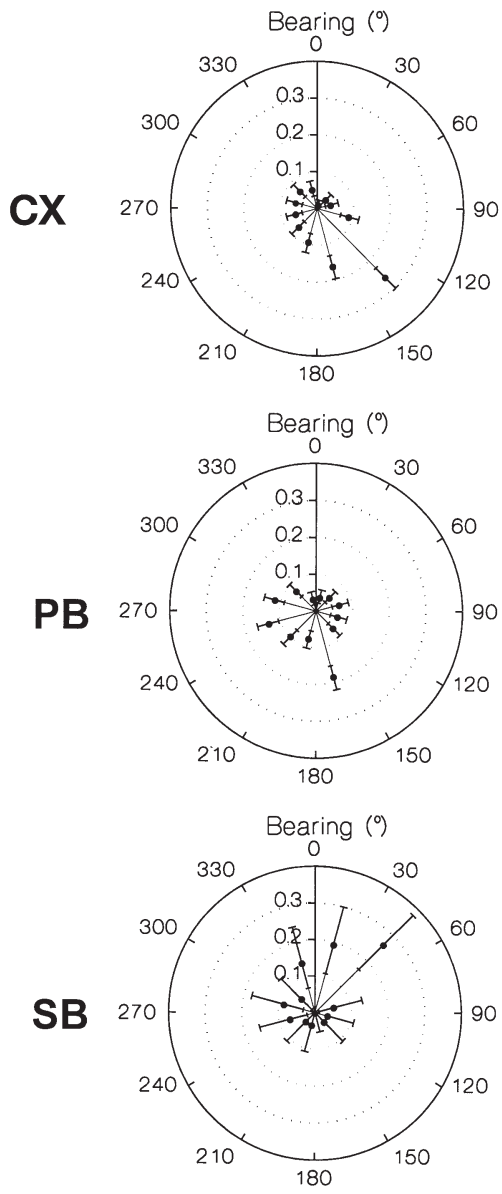

Fig. 3. Distribution of directions from release to recapture positions of tagged lobsters (for residual movements $>0.5 \mathrm{~km}$ ), with bearings in $30^{\circ}$ categories. Radial scale shows proportion of lobsters in each category, with binomial 95\% confidence limits. $\mathrm{CX}=$ Christchurch Ledge, $\mathrm{PB}=$ Poole Bay, $\mathrm{SB}=$ Swanage Bay

The distribution of directions moved $(>0.5 \mathrm{~km})$ differed among the 3 areas $\left(G_{24}=181.86, \mathrm{p} \ll 0.001\right)$. In Poole Bay, movements were predominantly between the south and south-southeast (bearings in the range 150 to $180^{\circ}$ ), but also with a considerable proportion of movements between southwest and northwest. At Christchurch Ledge, movements towards the southeast were most frequent, while at Swanage, most were to the north or northeast (Fig. 3). In Poole Bay, there was an interactive effect of sex and size category on direction moved $\left(G_{31}=53.90, \mathrm{p}=0.007\right)$, such that there was a greater tendency for movement to the west by larger lobsters, which was particularly marked in males. This interaction was not significant at Christchurch Ledge $\left(G_{27}=35.22, \mathrm{p}=0.133\right)$ and there were too few recaptures to test it in Swanage Bay.

In all 3 areas, the majority of the longer distance movements $(>5 \mathrm{~km})$ by both sexes were to the south-

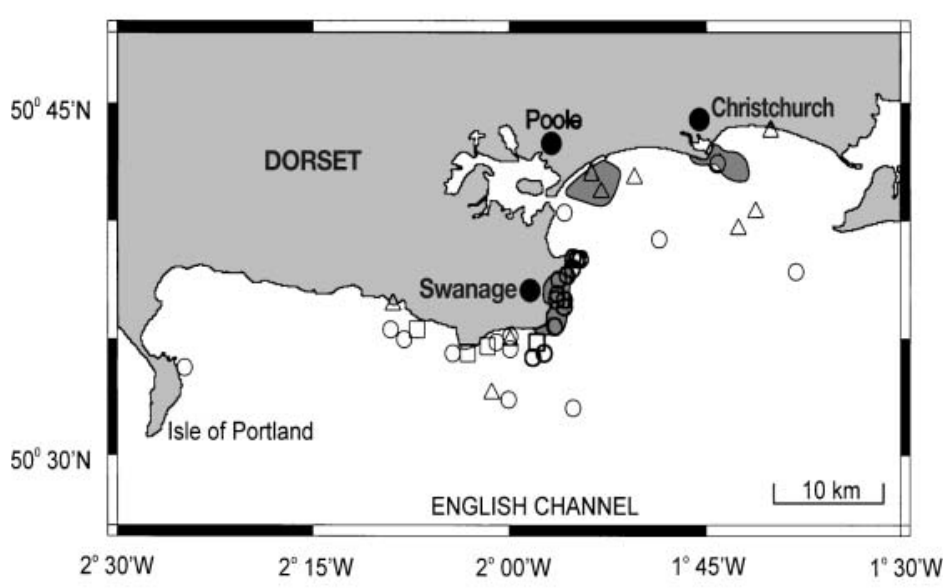

Fig. 4. Positions of tagged lobsters recaptured more than $5 \mathrm{~km}$ from release. Circles, triangles and squares indicate lobsters released in Poole Bay, at Christchurch Ledge and in Swanage Bay, respectively. Release areas shown by dark shading

west or west-southwest (Fig. 4). Only 1 lobster released in Poole Bay (of 976 relocated) was reported recaptured at Christchurch Ledge to the east and no lobsters released in Swanage Bay (out of 74 relocated) were reported recaptured in Poole Bay or at Christchurch Ledge. Three lobsters released at Christchurch Ledge (of 476 relocated) were recaptured in the Poole Bay fishery and 10 lobsters released in Poole Bay were recaptured in Swanage Bay.

Distance moved tended to increase gradually with time at liberty, but there was considerable variability in this relationship (Fig. 5). The strength of this relationship varied with the direction of movement for lob-

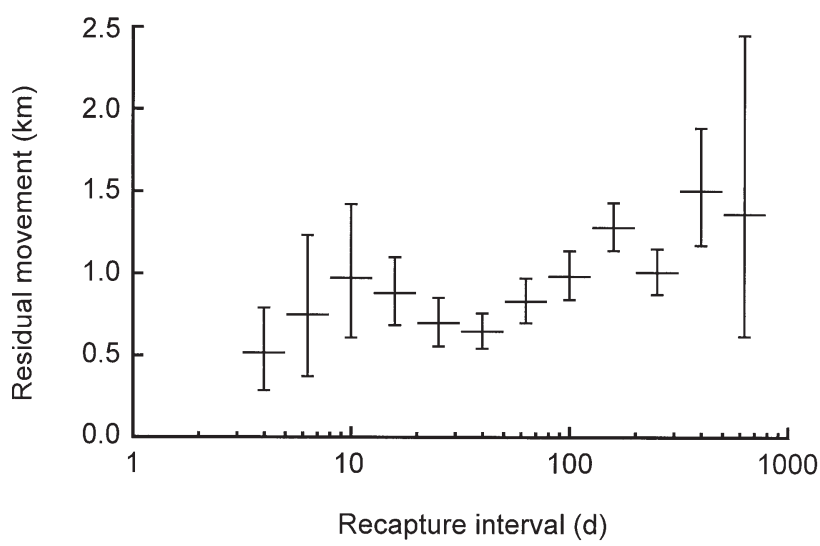

Fig. 5. Relationship between recapture distance and time at liberty for tagged lobsters, all release areas combined. For clarity, distance has been expressed as means and $95 \%$ confidence intervals calculated from log-transformed data in relation to categories of time at liberty. The horizontal line symbols span the time interval over which the mean was calculated 

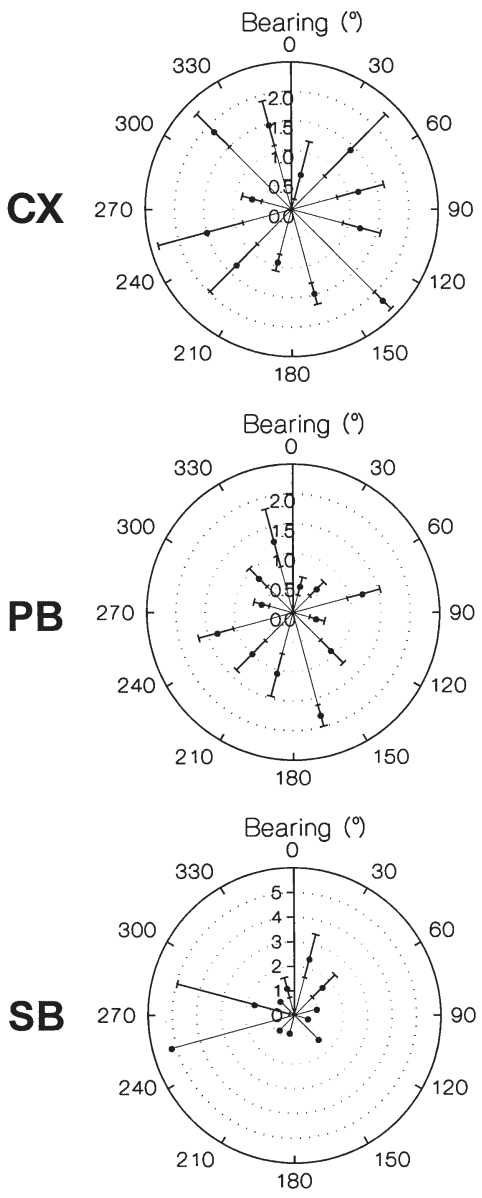

Fig. 6. Mean recapture distance of tagged lobsters (radial scale in $\mathrm{km}$ ) in relation to direction moved. Error bars are $95 \%$ confidence intervals (for $\mathrm{n} \geq 10$ ). $\mathrm{CX}=$ Christchurch Ledge, PB = Poole Bay, SB = Swanage Bay

sters released in Poole Bay $\left(F_{11,852}=2.73, \mathrm{p}=0.002\right)$ and was significant only for movements to the south-southwest, west-southwest and northwest. Recapture distance increased with time irrespective of direction moved by lobsters released at Christchurch $\left(F_{1,457}=\right.$ $12.4, \mathrm{p}<0.001)$ and Swanage $\left(F_{1,56}=15.0, \mathrm{p}<0.001\right)$. In these 2 areas, mean recapture distance varied significantly with direction (Fig. 6), with longest mean recapture distances to the southeast at Christchurch $\left(F_{11,457}=\right.$ $9.66, \mathrm{p} \ll 0.001)$ and to the north-northeast and westsouthwest at Swanage $\left(F_{10,56}=3.32, \mathrm{p}=0.002\right)$.

Distance moved was also weakly positively related to CL of lobsters released in Poole Bay $\left(F_{1,852}=11.4, \mathrm{p}\right.$ $=0.001$, partial $\left.\mathrm{r}^{2}=1.3 \%\right)$ and Swanage Bay $\left(F_{1,56}=\right.$ 5.78, $\mathrm{p}=0.020$, partial $\mathrm{r}^{2}=9.3 \%$ ), but not of lobsters released at Christchurch Ledge $\left(F_{1,455}=0.005, \mathrm{p}=\right.$ 0.944). Distance moved did not differ between male and female lobsters released in Poole Bay $\left(F_{1,851}=1.89\right.$, $\mathrm{p}=0.164)$, Christchurch $\left(F_{1,456}=0.09, \mathrm{p}=0.760\right)$ or Swanage $\left(F_{1,55}=0.110, \mathrm{p}=0.742\right)$.

\section{DISCUSSION}

The present study indicates that most lobsters Homarus gammarus of the size range tagged do not undertake extensive alongshore or on-/offshore movements. Most recaptures were made within $3.8 \mathrm{~km}$ of the corresponding release position and mean recapture distances in Poole Bay were only $0.8 \mathrm{~km}$. The widespread occurrence of lobster fishing along the south coast of England and the familiarity of the tag reporting scheme among fishermen make it likely that greater movements would have been detected if they had occurred, although it is possible that reporting rates were lower away from the release areas. The persistent tags used were capable of being retained for several years, but most recaptures were made within $1 \mathrm{yr}$ of initial release, which may have limited the scope for detecting longer movements. Nevertheless, there was only a very gradual and variable increase in distance moved with time at liberty up to $2 \mathrm{yr}(<1 \mathrm{~km}$ $\mathrm{yr}^{-1}$ ), suggesting that the range of movements detected was not severely constrained by the timescale of recaptures. The lower mean recapture distances of lobsters in Poole Bay compared with the other 2 areas may have been due to differences in the spatial configuration of available habitat. Similarity of recapture intervals suggests it was not largely due to differences in fishing intensity.

It should be noted that a considerable proportion of lobsters released in each area was not known to be recaptured (approximately half in Poole Bay and at Christchurch Ledge), leaving the possibility that they may have moved greater distances, to areas with no fishing, or with zero reporting rates. Other possible fates of lobsters not reported as recaptured are that they remained alive and at liberty within the study area, they died before possible recapture, they were recaptured having shed both tags, or they were recaptured without being reported. Natural mortality has only been determined for Homarus gammarus greater than $80 \mathrm{~mm} \mathrm{CL}$, yielding estimated death rates of 10 to $22 \% \mathrm{yr}^{-1}$ (Hepper 1978, Bannister 1986). Lobsters smaller than $80 \mathrm{~mm}$ CL within the size range tagged in the present study are expected to have somewhat higher mortality rates (Addison \& Bannister 1994). The estimated incidence of complete tag loss before recapture was comparatively low, but nonetheless constituted a further loss from the tagged sample. The proportion of recaptures not reported is unknown, but certainly non-zero. Despite these losses, recapture rates in this study were consistent with typical levels of fishing intensity on the south coast of England. Bannister (1986) estimated fishing mortality in south coast lobster fisheries from the size composition of the commercial catch (formerly $>80 \mathrm{~mm} \mathrm{CL}$ ), which equated to 
annual exploitation rates of 35 to $55 \%$, depending on sex and estimation method. These figures are comparable with 49 and $52 \%$ of tagged undersized lobsters recaptured within $1 \mathrm{yr}$ of release in Poole Bay and at Christchurch Ledge, respectively. (The lower recapture rate at Swanage, $26 \%$ within $1 \mathrm{yr}$, may have been due to lower fishing intensity, lower catchability, higher mortality, or a lower reporting rate). Since the number of lobsters not recaptured can be reasonably accounted for in terms of typical fishing intensity and likely losses, it seems unlikely that a substantial proportion of them made unobserved long distance movements.

The limited scale of movement seen in the present study corroborates the general findings of earlier studies of Homarus gammarus, in which the observable recapture intervals were limited by the use of tags that were lost at ecdysis (Thomas 1955, Simpson 1961, Gibson 1967, Hepper 1978). It is also consistent with the more intensive and extensive studies of $H$. americanus of comparable size to the lobsters used in the present study (Lawton \& Lavalli 1995, Estrella \& Morrissey 1997, Watson et al. 1999). The ecological consequences of the observed range of movement depend in part on what, if anything, limits movement. Lobster movements may be unrestricted, so that the range of movement simply reflects the area within which water conditions, such as temperature and salinity, are tolerable and vital resources are available. In the long term, this would imply sustainable use of prey populations, perhaps facilitated by the broad diet composition of $H$. gammarus (Hallbäck \& Warén 1972, Turner \& Warman 1991). However, it is likely that the range of movement is constrained by factors associated with the need to return to a shelter for protection from predation or adverse environmental conditions, such as severe water movement (Howard 1980).

If lobsters undertake return excursions from a 'home' shelter or group of shelters, rather than occupying a different shelter after each trip, their range of movement will be subject to aspects of the cost-benefit balance of central place foraging (Orians \& Pearson 1979), taking account of such factors as the spatial distribution of prey, the energetics of locomotion, time constraints and risk of predation. This may be the case if suitable shelters are sparse or patchily distributed. Even if shelters are more evenly distributed, intraspecific competition may be such that continued possession of a shelter is best achieved by returning to and defending the same one, at least in the short term. Across a wide range of taxa, resource holders have an advantage in contests for possession (Harper 1991) and there is evidence of individual lobsters inhabiting particular shelters for prolonged periods (Dybern et al. 1967, Ennis 1984, Karnofsky et al. 1989). If, in addition to defending shelters, lobsters defend a surrounding area (Ennis 1984, Karnofsky \& Price 1989, Duggan et al. 1991), distances travelled may be directly limited by agonistic interactions with dominant neighbours. Territorial disputes may also have a less direct but more general effect, by biasing the balance of costs and benefits of foraging against longer movements, even for dominant individuals (Milinski \& Parker 1991).

In contrast to the limited home ranges of juvenile Homarus spp., large, sexually mature Homarus americanus from offshore stocks (near the margin of the continental shelf) and those from some southern inshore stocks undertake seasonal return migrations of hundreds of kilometres to inshore areas (Lawton \& Lavalli 1995, Estrella \& Morrissey 1997). There are no known stocks of $H$. gammarus near the continental shelf margin, but large specimens are found several tens of kilometres offshore in isolated patches of suitable habitat, including shipwrecks (Bannister \& Addison 1995, pers. obs.). Since the reproductive contribution of large individuals in offshore refugia may help to sustain inshore stocks (Fogarty 1998, Sheehy et al. 1999), knowledge of their degree of mobility and an understanding of the effects of movement on vulnerability to exploitation and stock structure are desirable.

Most of the lobsters tagged in the present study were likely to have been sexually immature (Free et al. 1992), so the mobility of adult Homarus gammarus remains to be adequately studied with persistent tags. The rapid colonisation of an artificial reef in Poole Bay, some $3 \mathrm{~km}$ from known lobster habitat, by lobsters of larger average size than in the adjacent fishery (Jensen et al. 2000), and subsequent mark-recapture studies of those lobsters (Jensen et al. 1994), suggest that adult $H$. gammarus are more mobile than the size range examined in the present study, although they may also remain within small areas for prolonged periods (Smith et al. 1999, Jensen et al. 2000). Recent changes in lobster fishery legislation in the United Kingdom, which have increased the minimum landing size and prohibited the landing of 'V-notched' (Getchell 1987) lobsters, will facilitate the study of mobility in sexually mature $H$. gammarus, by permitting longer periods at liberty and increasing the chances of gaining information from multiple recaptures.

Although lobsters generally did not move far from release sites in the present study, movements $>0.5 \mathrm{~km}$ appeared not to be randomly directed, since they were more prevalent and longer in some directions than others. Furthermore, the directional pattern of movements differed among the 3 study areas, which were only 10 to $12 \mathrm{~km}$ apart. Clearly, the maximum possible distance of movements in some directions was limited by the presence of land, but most release positions were at least $0.5 \mathrm{~km}$ from shore, so landward movements 
were not excluded from the analysis. Such local differences in directionality may have gone undetected in previous studies of Homarus gammarus, perhaps because of limited accuracy of position fixing, because results were aggregated over larger areas, thus obscuring spatial heterogeneity, or because they were thought to be unimportant from contemporary fisheries management perspectives (Thomas 1955, Simpson 1961, Gibson 1967, Hepper 1978). In the present study, short-range movements appeared to be largely influenced by the spatial distribution of suitable habitat (which would also have been reflected in the spatial distribution of fishing effort). At Christchurch Ledge, in particular, recorded movements were mainly along the pronounced northwest/southeast axis of the bedrock outcrop. In Poole Bay, a considerable proportion of movements was along bands of bedrock and boulders which lie approximately parallel to the shore. The modal direction of movement in Poole Bay, however, lay between south and southeast, from rocky areas $0.5 \mathrm{~km}$ from the shore to patches of similar ground $2 \mathrm{~km}$ further offshore. There were comparatively few recaptures indicating movement in the opposite direction, despite high fishing effort on the inshore rocky areas. The predominant direction of movement along Christchurch Ledge was also apparently offshore (southeast).

The tendency for offshore movement in the size range of lobsters studied may reflect changing habitat requirements, perhaps in response to increasing body size or sexual maturation. Such habitat shifts occur in many other decapod species and have been suggested for Homarus gammarus (Howard 1980). Ontogenetic habitat shifts, even if on a small spatial scale, would be expected to generate relationships between distance or direction of movement, and age or body size. There was some evidence of this nature, in that larger Poole Bay males exhibited a greater tendency to move to the west and distance moved by both sexes was positively related to body size, but the angular distribution of movements by females did not change as markedly with body size and the distance/body size relationship (taking account of time at liberty) was weak. Ontogenetic habitat shifts would be difficult to detect if habitat preferences were more closely related to chronological age than body size, since there appears to be considerable variability in growth rates in $H$. gammarus (Sheehy et al. 1999). However, it is likely that shelter size requirements, at least, are more closely related to body size than age (Cobb 1971).

Despite the differences in the angular distribution of local movements among the 3 study areas, longer movements $(>5 \mathrm{~km})$ from all 3 release areas, which usually involved movement to a different fishing area and which comprised $5.2 \%$ of recaptures after more than 6 mo, were almost exclusively to the west or southwest. The lack of recaptures to the east was not due to a lack of fishing effort in that direction. Movements of this magnitude were undertaken mainly, but not exclusively, by lobsters in the upper half of the size range tagged, suggesting that these movements may be associated in some way with increasing body size or sexual maturation. Several species of decapod undertake contranatant migrations, in some cases prior to sexual maturation, that are thought to be important in maintaining larval recruitment to suitable habitat, especially when habitat is patchily distributed (Edwards 1979, Bennett \& Brown 1983, Lawton \& Lavalli 1995, Lipcius \& Cobb 1994, Booth 1997). In the English Channel, where the general direction of tide- and wind-generated residual water movement is to the east, adult brown crabs Cancer pagurus undertake westward spawning migrations of tens or hundreds of kilometres (Bennett \& Brown 1983). It has been suggested previously that contranatant movements may occur in some Homarus gammarus populations (Meek 1925, Graham 1949, but see Addison \& Lovewell 1991), but average distances travelled appear to be much less than in C. pagurus, despite similar durations of the larval planktonic phase in the 2 species (Edwards 1979, Phillips \& Sastry 1980). Data on the distance and direction of movements by larger, adult lobsters and on larval transport, particularly in areas subject to substantial residual water movement, are needed to further assess the significance of the up-current bias in longer movements observed in the present study.

Acknowledgements. This study was funded by the Ministry of Agriculture Fisheries and Food. We are grateful to Colin Bannister and Julian Addison (CEFAS Lowestoft) for support and advice, to Brian Mullins, Brian Stride and Alan Lander for allowing us to work on their vessels, to the various students who helped with sampling, to all those who reported recaptures, to Andrew Perry (MAFF, Poole) for dealing with local tag returns, to Neil Turner (Bournemouth Borough Council) for supplying temperature data, and to Kate Davis for graphical assistance.

\section{LITERATURE CITED}

Addison JT, Bannister RCA (1994) Re-stocking and enhancement of clawed lobster stocks: a review. Crustaceana 67: $131-155$

Addison JT, Bannister RCA (1998) Quantifying potential impacts of behavioral factors on crustacean stock monitoring and assessment: modeling and experimental approaches. In: Jamieson GS, Campbell A (eds) Proceedings of the North Pacific Symposium on Invertebrate Stock Assessment and Management. Can Spec Publ Fish Aquat Sci 125:167-177

Addison JT, Lovewell SRJ (1991) Size composition and pot selectivity in the lobster (Homarus gammarus (L.) and crab (Cancer pagurus L.) fisheries on the east coast of England. ICES J Mar Sci 48:9-90 
Andrew NL, MacDiarmid AB (1991) Interrelations between sea urchins and spiny lobsters in northeastern New Zealand. Mar Ecol Prog Ser 70:211-222

Arnold GP, Greer Walker M, Holford BH (1990) Fish behaviour: achievements and potential of high-resolution sectorscanning sonar. Rapp P-V Réun Cons Int Explor Mer 189: 112-122

Bannister RCA (1986) Assessment and population dynamics of commercially exploited shellfish in England and Wales. In: Jamieson GS, Bourne N (eds) Proceedings of the North Pacific Workshop on stock assessment and management of invertebrates. Can Spec Publ Fish Aquat Sci 92: 182-194

Bannister RCA, Addison JT (1995) Investigating space and time variation in catches of lobster (Homarus gammarus (L.)) in a local fishery on the east coast of England. ICES Mar Sci Symp 199:334-348

Bannister RCA, Addison JT (1998) Enhancing lobster stocks: a review of recent European methods, results and future prospects. Bull Mar Sci 62:369-387

Bannister RCA, Addison JT, Lovewell SRJ (1994) Growth, movement, recapture rate and survival of hatchery-reared lobsters (Homarus gammarus Linnaeus, 1758)) released into the wild on the English east coast. Crustaceana 67: 156-172

Barkai A, Branch GM (1988) The influence of predation and substratal complexity on recruitment to settlement plates: a test of the theory of alternative states. J Exp Mar Biol Ecol 124:215-237

Bennett DB, Brown CG (1983) Crab (Cancer pagurus) migrations in the English channel. J Mar Biol Assoc UK 63: 371-398

Bennett DB, Lovewell SRJ (1983) Lobster (Homarus gammarus (L.) tagging trials in England. Fish Res Tech Rep Dir Fish Res (GB) 71:1-7

Booth JD (1997) Long-distance movements in Jasus spp. and their role in larval recruitment. Bull Mar Sci 61:111-128

Chittleborough RG (1974) Development of a tag for the western rock lobster. Report 56, CSIRO Australia Division of Fisheries and Oceanography Marine Laboratory, Cronulla, Sydney

Cobb JS (1971) The shelter related behaviour of the lobster Homarus americanus. Ecology 52:108-115

Collins KJ, Jensen AC (1992) Acoustic tagging of lobsters on the Poole Bay artificial reef. In: Priede IG, Swift SM (eds) Wildlife telemetry. Remote monitoring and tracking of animals. Ellis Horwood, London, p 354-358

Duggan RE, Pringle JD, Webber DM, O'Dor RK (1991) Tracking lobster movement using ultrasonic transmitters. J Shellfish Res 10:282

Dybern BI, Jacobsson L, Hallbäck H (1967) On the habitat behaviour of the lobster (Homarus vulgaris) in Swedish waters. Meddn Havsfisklab Lysekil 36:1-7

Ebling FJ, Kitching JA, Muntz L, Taylor CM (1964) The ecology of Lough Ine. XIII. Experimental observations of the destruction of Mytilus edulis and Nucella lapillus by crabs. J Anim Ecol 33:73-82

Edwards E (1973) The European lobster (Homarus gammarus) and its fishery in England and Wales. Report, Ministry of Agriculture, Fisheries and Food Fisheries Laboratory, Burnham-on-Crouch, Essex

Edwards E (1979) The edible crab and its fishery in British waters. Fishing News Books Ltd, Farnham, Surrey

Efron B, Tibshirani RJ (1998) An introduction to the bootstrap, 2nd edn. Monographs on Statistics and Applied Probability 57. Chapman and Hall/CRC, Boca Raton, FL

Ennis GP (1972) Growth per moult of tagged lobsters
(Homarus americanus) in Bonavista Bay, Newfoundland. J Fish Res Board Can 29:143-148

Ennis GP (1984) Territorial behavior of the American lobster Homarus americanus. Trans Am Fish Soc 113:330-335

Estrella BT, Morrissey TD (1997) Seasonal movement of offshore American lobster, Homarus americanus, tagged along the eastern shore of Cape Cod, Massachusetts. Fish Bull (Wash DC) 95:466-476

Fisher NI (1993) Statistical analysis of circular data. Cambridge University Press, Cambridge

Fogarty MJ (1995) Populations, fisheries, and management. In: Factor JR (ed) Biology of the lobster, Homarus americanus. Academic Press, San Diego, p 111-137

Fogarty MJ (1998) Implications of migration and larval interchange in American lobster (Homarus americanus) stocks: spatial structure and resilience. In: Jamieson GS, Campbell A (eds) Proceedings of the North Pacific Symposium on Invertebrate Stock Assessment and Management. Can Spec Publ Fish Aquat Sci 125:273-283

Free EK, Tyler PA, Addison JT (1992) Lobster (Homarus gammarus) fecundity and maturity in England and Wales. ICES CM 1992:K43

Getchell RG (1987) Effects of V-notching on the lobster, Homarus americanus. Can J Fish Aquat Sci 44:2033-2037

Gibson FA (1967) Irish investigation on the lobster (Homarus vulgaris Edw.). Ir Fish Invest Ser B (Mar) 1:13-45

Graham M (1949) A note on the theory of a dwarf race of lobsters on the Norfolk coast. J Mar Biol Assoc UK 28: $481-487$

Gray MJ (1995) The coastal fisheries of England and Wales, Part III: a review of their status 1992-1994. Fish Res Tech Rep Dir Fish Res (GB) 100:1-99

Gundersen KR (1962) Tagging experiments on lobster, Homarus vulgaris, in Norway. Ann Biol (CPH) 19:189

Hallbäck H, Warén A (1972) Food ecology of the lobster, Homarus vulgaris, in Swedish waters. Some preliminary results. ICES CM 1972:K29

Harper DGC (1991) Communication. In: Krebs JR, Davies NB (eds) Behavioural ecology. An evolutionary approach. Blackwell Scientific Publications, Oxford, p 374-397

Hepper BT (1978) Population dynamics of the lobster Homarus gammarus (L.) off the coasts of England. Fish Res Tech Rep Dir Fish Res (GB) 41:1-29

Herrnkind WF (1983) Movement patterns and orientation. In: Vernberg FJ, Vernberg WB (eds) The biology of Crustacea, Vol. 7. Behavior and ecology. Academic Press, New York, p 41-105

Howard AE (1980) Substrate controls on the size composition of lobster (Homarus gammarus) populations. J Cons Int Explor Mer 39:130-133

Jefferts KB, Bergman PK, Fiscus HF (1963) A coded wire identification system for macro-organisms. Nature 198: $460-462$

Jensen AC, Collins KJ, Free EK, Bannister RCA (1994) Lobster (Homarus gammarus) movement on an artificial reef: the potential use of artificial reefs for stock enhancement. Crustaceana 67:198-211

Jensen A, Wickins J, Bannister C (2000) The potential use of artificial reefs to enhance lobster habitat. In: Jensen AC (ed) Artificial reefs in European seas. Kluwer Academic Publishers, Dordrecht, p 379-401

Karnofsky EB, Price HJ (1989) Dominance, territoriality and mating in the lobster, Homarus americanus: a mesocosm study. Mar Behav Physiol 15:101-121

Karnofsky EB, Atema J, Elgin RH (1989) Field observations of the social behaviour, shelter use, and foraging in the lobster Homarus americanus. Biol Bull 176:239-246 
Latrouite D (1998) The French experience with enhancement of European lobster Homarus gammarus. Can Ind Rep Fish Aquat Sci 244:55-58

Lawton P, Lavalli KL (1995) Postlarval, juvenile, adolescent, and adult ecology. In: Factor JR (ed) Biology of the lobster Homarus americanus. Academic Press, San Diego, p 47-88

Lipcius RN, Cobb JS (1994) Ecology and fishery biology of spiny lobsters. In: Phillips BF, Cobb JS, Kittaka J (eds) Spiny lobster management. Fishing News Books, Oxford, p 1-30

Lovewell SR (1991) Observations on the by-catch of lobsters (Homarus gammarus L.) by trawlers off the Yorkshire coast, England. ICES CM 1991:K19

Meek A (1925) Experimental legislation with reference to the crab and lobster fisheries of the east coast of Britain. J Mar Biol Assoc UK 13:755-768

Milinski M, Parker GA (1991) Competition for resources. In: Krebs JR, Davies NB (eds) Behavioural ecology. An evolutionary approach. Blackwell Scientific Publications, Oxford, p 137-168

Miller RJ (1990) Effectiveness of crab and lobster traps. Can J Fish Aquat Sci 47:1228-1251

Neter J, Kutner MH, Nachsheim CJ, Wasserman W (1996) Applied linear statistical models, 4th edn. Irwin, Chicago

Orians GH, Pearson NE (1979) On the theory of central place foraging. In: Horn DJ, Stairs GR, Mitchell RD (eds) Analysis of ecological systems. Ohio State University Press, Columbus, Ohio, p 155-177

Perry RI, Walters CJ, Boutilier JA (1999) A framework for providing scientific advice for the management of new and developing invertebrate fisheries. Rev Fish Biol Fish 9:125-150

Phillips BF, Sastry AN (1980) Larval ecology. In: Cobb JS, Phillips BF (eds) The biology and management of lobsters, Vol. 2. Ecology and management. Academic Press, New York, p 11-57

Robles C, Robb J (1993) Varied carnivore effects and the prevalence of intertidal algal turfs. J Exp Mar Biol Ecol 166:65-91

Scarrat DJ, Elson PF (1965) Preliminary trials of a tag for salmon and lobsters. J Fish Res Board Can 22:421-423

Scheibling RE (1996) The role of predation in regulating sea urchin populations in eastern Canada. Oceanol Acta 19: 421-430

Seber GAF (1982) The estimation of animal abundance and related parameters, 2nd edn. Griffin, London

Sheehy MRJ, Bannister RCA, Wickins JF, Shelton PMJ (1999) New perspectives on the growth and longevity of the European lobster (Homarus gammarus). Can J Fish Aquat Sci 56:1904-1915

Simpson AC (1961) A contribution to the bionomics of the lobster (Homarus vulgaris Edw.) on the coast of North Wales. Fish Investig Ser II 23:1-28

Editorial responsibility: Otto Kinne (Editor),

Oldendorf/Luhe, Germany
Smith GW, Urquhart GG, MacLennan DN, Sarno B (1998) A comparison of theoretical estimates of the errors associated with ultrasonic tracking using a fixed hydrophone array and field measurements. Hydrobiologia 371/372: $9-17$

Smith IP, Collins KJ, Jensen AC (1998a) Electromagnetic telemetry of lobster (Homarus gammarus (L.) movements and activity: preliminary results. Hydrobiologia 371/372: 133-141

Smith IP, Collins KJ, Jensen AC (1998b) Movement and activity patterns of the European lobster, Homarus gammarus, revealed by electromagnetic telemetry. Mar Biol 132:611-623

Smith IP, Collins KJ, Jensen AC (1999) Seasonal changes in the level and diel pattern of activity in the European lobster Homarus gammarus. Mar Ecol Prog Ser 186: 255-264

Smith IP, Collins KJ, Jensen AC (2000) Digital electromagnetic telemetry system for studying behaviour of decapod crustaceans. J Exp Mar Biol Ecol 247:209-222

Sokal RR, Rohlf FJ (1995) Biometry. The principles and practice of statistics in biological research, 3rd edn. WH Freeman and Co., New York

Spanier E, Tom M, Pisant S, Almog G (1988) Seasonality and shelter selection by the slipper lobster Scyllarides latus in the southeastern Mediterranean. Mar Ecol Prog Ser 42: $247-255$

Sutherland WJ (1996) From individual behaviour to population ecology. Oxford University Press, Oxford

Thomas HJ (1955) Observations on the recapture of tagged lobsters in Scotland. Mar Res Ser Scot Home Dep 1955-2: $1-12$

Turner JR, Warman CG (1991) The mobile fauna of sublittoral cliffs. In: Myers AA, Little C, Costello MJ, Partridge JC (eds) The ecology of Lough Hyne. Proceedings of a conference, 4-5 September 1990. Royal Irish Academy, Dublin, p 127-138

van der Meeren GI (1997) Preliminary acoustic tracking of native and transplanted European lobsters (Homarus gammarus) in an open sea lagoon. Mar Freshw Res 48: 915-921

Vannini M, Cannicci S (1995) Homing behaviour and possible cognitive maps in crustacean decapods. J Exp Mar Biol Ecol 193:67-91

Watson WH III, Vetroves A, Howell WH (1999) Lobster movements in an estuary. Mar Biol 134:65-75

Wilkinson L, Hill M, Welna JP, Birkenbeuel GK (1992) Systat for Windows: Statistics, Ver 5 edn. Systat Inc., Evanston, Illinois

Yamada SB, Boulding EG (1996) The role of highly mobile crab predators in the intertidal zonation of their gastropod prey. J Exp Mar Biol Ecol 204:59-83

Submitted: September 15, 2000; Accepted: March 22, 2001

Proofs received from author(s): October 19, 2001 